\title{
An Exploratory Investigation into the Role of a Research and Development Programme on Future Craft Practice
}

\begin{abstract}
:
Purpose: this paper assesses the effectiveness of a research and development programme on improving craft practice through the provision of mentoring by academic practitioners, studio space and advice on marketing techniques.

Design/methodology/approach: following an initial focus group investigation of issues which impinge on contemporary craft practice, recipients of a bursary associated with the research and development programme were assessed with respect to how their craft and marketing competencies have developed.
\end{abstract}

Findings: practitioners can now reflect on their skills, experiment with techniques and consider the effectiveness of their approach and attitude towards marketing.

Research limitations/implications: the programme only extends to practitioners working with one art and design institution but has implications for those concerned with creative practice elsewhere.

Practical implications: there is wider potential to reinvigorate artistic and marketing practice across the creative and cultural industries, and the small and medium enterprise community in general.

Social implications: the role of the third level art and design institution extends into the social world through its ability to challenge existing practices and develop more creative and innovative alternatives.

Originality/value: this is a novel programme which challenges experienced practitioners to extend their creative abilities in craft and approaches to marketing.

Paper type: research paper

Key words: craft, competencies, design, marketing, experimentation, mentoring

Citation: Louise Valentine, Ian Fillis, Georgina Follett, (2013) "An exploratory investigation into the role of a research and development programme on future craft practice", Arts Marketing: An International Journal, Vol. 3 Iss: 2, pp.95-116

\section{Introduction:}

This paper assesses the effectiveness of a research and development programme on improving contemporary competencies in craft practice through participation in a mentoring 
programme at a third level art and design college within a Scottish university. Positive outcomes from the programme include improved personal confidence for sole practitioners who had no previous available support in shaping development of their work and approach to marketing, increased quality and range of innovative products being designed and produced and acquisition of greater technical knowledge and skills. Other advantages of participation in the programme include improved evaluation of appropriate new audience development practices, extending professional networks and reaching new markets. The paper is structured as follows. The literature review explains the research context by evaluating the origins and economic contribution of craft. A discussion of its contemporary impact is developed, assisted by appraisal of recent research from craft and marketing perspectives. A two part methodology is utilised, with a focus group of key informants followed by in-depth interviews of participants in the craft mentoring scheme. Thematic analysis of the data is carried out and implications for theory and practice are discussed.

\section{Literature review and contextual analysis of the crafts economy: is there a need for change?}

Craft can be traced to the Medieval period (Heslop 1997) through to the present day (Hillman-Chartrand 1988; Knott 1994; Follett and Valentine 2007; Greenhalgh 2010; Von Busch 2010). The nature and meaning of craft has evolved, from its early vernacular status to more recent aesthetic appreciation of the craft product (Kristeller 1951; Dean 1994) and strategic appreciation as a radical, innovative process (Yair et al. 2001; Marshall 2007; Adamson 2010). Its present connotations draw from a variety of disciplines, including philosophy, aesthetics and technology. Craft can refer to studio crafts, from producers of functional ware to abstractionalist sculptors working in textiles, clay or glass, or as a process 
over which an individual has detailed control, shaped by in-depth craft knowledge (Dormer 1997). Metcalf (1997) distinguishes between craft as skilful labour and craft as a class of objects which have a high degree of hand-made input. Both the Scottish Arts Council, now part of Creative Scotland, and the Crafts Council of England and Wales, choose to focus on contemporary craft as part of the wider visual arts and design. In contrast, the Crafts Council of Ireland also embeds craft within the wider small business community where unique identity, innovation, quality and competitiveness are contributing factors.

Despite being defined repeatedly, craft still remains elusive as a category, practice and discipline (Niedderer and Townsend 2010). It has been viewed as a distinct discipline, as a paradigm of working and as an art form (Risatti 2007). Craft can be basic in form, a valuable artefact or even ritualised with higher levels of meaning relating to its design and utility (Miller 2009). Fillis (2002; 2004) has defined craft as having a high degree of hand-made input, but not necessarily manufactured using traditional materials. It should be produced as a one-off or as part of a small batch, the design of which may or may not be culturally embedded in the country of production, and which is sold for profit. Valentine (2010) captures several additional influences, including cultural, economic and political aspects of the environment, the Bauhaus, modernism, consumerism, progressivism, postmodernism, digital media and the growth of craft theory. She believes in the value of developing craft knowledge as a set of principles where its meaning, purposes, aesthetic and economies are dynamic and transformative. Adamson (2010) urges us to enjoy a simple, open-ended definition:

the application of skill and material based knowledge to relatively small scale production...[as] it allows us to draw connections across a much wider range of 
activities than the so-called 'crafts' themselves [such as ceramics, glass-making, textiles].

In doing so he negates the need to categorise craft and seeks to champion or emphasis its inherent boundary crossings with art and design, preferring to accept diversity and transformation of form and meaning in all of craft's cultural and historical contexts.

Annual income for the majority of professional craft practitioners in the UK is approximately $£ 16,000$, significantly less than the national average wage (£22,568 in July 2011 www.ons.gov.uk). This reality is frustrating beyond measure for many professional craft practitioners who must often migrate into other areas of employment to ensure economic survival. In relation to the market, the crafts tend to operate using a product-focused model rather than developing a balanced product and market focus (Enright 1999). This is due to the impact of the nature of the industry environment on the market orientation-performance relationship (Day and Wensley 1988). In the arts, product orientation often dominates over customer orientation. This model preference can also be attributed to practitioners looking to develop the aesthetic integrity of their work, striving to enhance quality and develop their intellect through the creation of a new portfolio of work. The risk associated with the practitioner's aesthetically led approach to product development is that crafts can be perceived as simply following a maker's personal taste with insufficient attention to market development. Yet, in order to survive in the market, craft must have a personal visual signature that identifies and defines itself amongst a deluge of mass manufactured objects. Film theorists call this the indexical (Doane 2003). 
A second challenge posed by this informal business model means it is increasingly difficult for a craft practitioner to invest in research and development, which in turn restricts product innovation and business growth (Marshall 2007). A third contribution to crafts' downfall in the marketplace has been its tendency to take itself overtly seriously and limit itself to an exclusive customer base. Infighting has perpetually haunted the sector, hindering its full potential in the marketplace. Turner Prize winner Grayson Perry (2006, cited in Adamson, 2010: 553) comments upon this perception of craft by the marketplace and its implication:

'Craft, I think, to people outside the exquisitely constructed ring fence of the Craft Council has become a hobby. It is a leisure activity practised by exhibitors at craft fairs who fashion novelty covers for vacuum cleaners and children who are bought bead jewellery kits by well-meaning aunts who think they watch too much television. Craft has become an overblown Blue Peter project. Craft is becoming a zoo-bred animal that could not survive in the wild of the marketplace'.

\section{Craft within the context of the creative and cultural industries:}

In today's post industrialisation era, the craftsperson has to compete with both domestic and foreign competition where many products appear hand-crafted even though they are often mass produced using advanced technological processes. Recent literature suggests that craft be viewed as part of the greater cultural and creative industries (Hartley 2005; Hesmondhalgh 2007). Current studies, although significant in identifying potential impact, may have underestimated the value of craft by up to forty per cent, with the cumulative value of the industry potentially much greater than previously estimated (Pratt 2004; Roodhouse 2006; Higgs and Cunningham 2008). Ignoring those craft firms which have embraced mass production techniques and which therefore are no longer strictly craft based, the vast majority of craft businesses are microenterprises employing less than ten people (Storey 1994).

The economic contribution of craft: 
A number of UK surveys have examined the socio-economic impact of craft, including craft practitioners' future hopes in developing their work (Millman 2006; Platinum Consulting Group 2006; Scotinform 2007; BOP Consulting 2012). McAuley and Fillis (2002) estimated that the sector turnover in Scotland was $£ 151 \mathrm{~m}$ with nearly three quarters wishing to expand their practice. McAuley and Fillis (2004) also estimated that the turnover for English and Welsh makers was $£ 826 \mathrm{~m}$, with an almost similar proportion wishing to grow their work. A total sectoral turnover of around $£ 26 \mathrm{~m}$ is possible within Northern Ireland (McAuley and Fillis 2006). The Morris Hargreaves McIntyre report (2006) estimates the total market for craft in England and Wales to be $£ 883 \mathrm{~m}$, with a further growth potential of another two thirds. The Futurefocus report (HiArts et al. 2009) on developing audiences for Scottish craft found that, even though it suffered from a low media profile and lack of public awareness, estimated collective turnover by at least 2,500 people working in the sector was in the region of $£ 95 \mathrm{~m}$. A key concern related to worries over the quality of craft and impediments to greater engagement with craft included a lack of time and confidence, lack of interest and information on how to become involved in making. The Futurefocus survey also found that makers were least likely to make changes to their core product once their style had been developed. The McAuley and Fillis surveys, for example, utilised the Fillis (2002; 2004) definition of craft and utilised large scale surveys, in-depth interviews and case studies. The Craft in an Age of Change report used focus groups, expert interviews and a telephone survey of 2,000 makers, retailers, educators and curators. It did not impose a rigid definition of craft based on the materials used or the disciplines practiced. These surveys tended to focus on the number and type of craft businesses rather than endeavour to provide a break down in terms of new ventures and failure rates. A challenge to any potential for growth and change is the sharp reduction of economic investment in the crafts by public sector bodies and the viability 
of craft as a sustainable career path that meets the financial and creative imperatives of the individual (Galloway et al. 2002; McAndrew 2002; Davies and Lindley 2003). To date, access to public money via creative development awards have been central to the craft practitioner's business model. Therefore, it is reasonable to suggest an alternative approach to developing the core product(s) of a craft business is required to support sustainability and growth.

\section{The Business of Craft Practice:}

Practitioners develop their craft over a lifetime, establishing a way of working which involves searching and researching in an attempt to resolve technical, material and financial issues in the production of work in order to survive economically (Stevenson and Scobie 2007; Stevenson 2007). The ideal scenario is that, as practice and ideas mature, recognition comes and a market identity begins to be established, thereby enabling a greater amount of time to be dedicated to research and development. However, the reality can be somewhat different. Traditionally, the business of being a craftsperson is about financial survival, producing work that will sell. It is not until a craft practitioner has a reputation can they begin to fully explore their creativity, spending time on developing each idea, enabling higher quality craft and subsequently a higher 'asking' price for the work. One of the main methods of developing a craft business and growing in the marketplace is exhibition. This is evidenced in the plethora of events staged annually by organisations such as the Victoria and Albert Museum, Crafts Council, the Dovecot and National Museums Scotland. Exhibition is a primary means of selling work, demonstrating artistic ability, cultural sensitivity, political positioning, aesthetic sensibility and intellectual integrity. Exhibiting is a way of connecting practitioners with the public and provides an opportunity for practitioners to assess their 
personal values and aesthetic direction. It is a way of educating and exchanging knowledge, skills and expertise. It can also be a means of attracting a patron.

Within the business of craft practice there are a range of issues currently hindering the method of exhibition as an economically effective business tool, including the high cost of creating an exhibition which compromises the economic viability when selling the individual pieces of craft within the exhibition. Secondly, there is an over reliance on the practitionergallery/organisation partnership and the championing of a particular 'style' or genre of craft. In turn, the craft practitioner is heavily reliant on the success of the gallery in the marketplace rather than the power of their own brand (Schroeder 2005). This appears to be especially true of mid-career craft practitioners who have yet to consolidate their brand in the marketplace.

The literature review and contextual observation of craft in the marketplace highlights a need for change in craft as a creative marketing practice, if for no other reason that the annual wage for professional practitioners is $29 \%$ lower than the national average. In essence, one interpretation of this review is a need to investigate what is effective for securing the future of craft and to understand why the market is not working as well as it could and what needs to be done to make it work better.

\section{Research design and consideration of findings:}

The exploratory investigation adopted a two-part methodology (Figure 1). The aim was to develop a model for facilitating change to enhance creative and economic performance in professional craft practice. The wider objectives included devising and testing a new financial infrastructure, a resource infrastructure and a mentoring programme for mid-career Scottish 
craft professionals as a means of raising the level of innovation in practice. This paper focuses on the mentoring programme rather than the new financial and resource infrastructures and, while reference to the latter is made, it is not discussed here.

\begin{tabular}{|l|l|}
\hline \multicolumn{2}{|l|}{ Research Design } \\
\hline \multirow{3}{*}{ Part 1 } & $\begin{array}{l}\text { a) Literature Review and Contextual Analysis } \\
\text { b) Focus Group using key informant technique }\end{array}$ \\
\hline Part 2 & Case Study \\
& a) Design an Innovation Development programme and test it \\
& b) Interview selected participants \\
& c) Evaluate Mentoring aspect of programme \\
& d) Evaluate the model for Innovation
\end{tabular}

Figure 1: An overview of the 2-part methodology employed in the exploratory investigation for future craft practice.

\section{Research Design Part 1:}

The focus group method (Wilkinson 2004) was employed in order to evaluate craft from a marketing perspective. Scottish craft was chosen for its wider representation of craft in the UK economy and also because of the perceived failure to act on previous initiatives. The focus group was used as it is a qualitative approach, appropriate for exploratory studies and is used to collect data from a small number of people through group discussion around a particular topic or series of issues. A quantitative approach would have set restrictions on the research from the outset, whereas a qualitative approach allows for refinement and reworking of the research questions as the data is uncovered (Blackler and Brown 1983; Bryman and Burgess 1995). A moderator poses the questions to the group rather than to individuals, also ensuring that participants keep to the point while also encouraging interaction among group members (Morgan 1988). A key objective in the planning of the focus group was the 
selection of individuals with differing experiences from local, national and international perspectives in both public and private sectors. The key informant technique (Gilchrist 1992) was used to elaborate upon the different lenses with which to view the economies of craft; e.g. cultural, political, intellectual, social and financial perspectives. Each individual had an established portfolio of experience in creative practice, business, economics, marketing, enterprise and politics, including leadership within his or her field. The rationale was that each lens brought with it an alternative method to evaluate and debate the economy of craft practice. A group of six professionals were invited and all agreed to take part. These were the senior economic advisor of a global bank with responsibility at U.K. government level for providing economic intelligence, the leader of an international craft organisation, a craft practitioner with over thirty years' experience, a leading researcher and author in the field of SME marketing, with craft expertise, a national enterprise officer and a senior curator from an internationally recognised institution. In the context of craft, bringing together a plurality of perspectives and knowledge domains is unusual. It is more conventional to seek reference from within the sector and nurture debate across the sector rather than exchange knowledge and learn from other fields of knowledge and expertise. The advantages of the adopted approach, however, were that the diverse panel membership attended to the need for change from a strategic point of view, identified through the literature review and contextual analysis.

The main objective of the focus group was to identify and prioritise the various issues concerning economic difficulties in the craft sector. The group considered the weight and values placed by the different sector bodies on craft; for example, national craft agendas on social inclusion and cultural development, statistical analysis of craft businesses and 
employment data, articulation of the market for crafts including the public's perception of purchasing, aesthetic, technical and material imperatives of craft practice, political and cultural agendas associated with curating craft, capitalising on innovation within craft processes and exploitation of craft practitioner's intellectual property.

\section{Findings Part 1:}

The discussion about craft as a lost or rapidly deteriorating economy ensued over three meetings lasting a total of eight hours. A record of conversation from each meeting was taken by a professional minute taker and agreed prior to beginning the next discussion. The series of conversations was collated and analysed. Assessment of individual responses was not sought, as the intention was to create an integrated perspective from the knowledge and insight of experts from their different backgrounds. Analysis concentrated on identifying the observations made over the duration of the focus group meetings, with no attempt made to prioritise the issues. The key observations made by the group were that significant investment in the development of craft was made between 2000-2007 and positive work had been undertaken both within and between the various craft stakeholders, including agencies, councils, curators, galleries, museums and practitioners. However, there was also poor visibility and inadequate return on investment. The period of time to action important outcomes from major reports was too long and there was insufficient pooling of resources to form a connected strategy. So despite the investment, there has been little meaningful impact. The external environment, the politics and the reasons for economic difficulties in craft in Scotland were also reviewed as a means of understanding the problematic economy of craft. The Crafts Council of Ireland's model was analysed as it offered a significantly different approach to the one used within the U.K. It places craft in the context of enterprise whereas 
within the U.K. craft operates within the context of arts and culture. The funding mechanisms, policies and vision for the Irish craft sector are driven and evaluated by intellectually different questions and frameworks.

The key outcomes were that new knowledge and understanding of the economies of craft in terms of supply and demand and their inter-relationships were required because of the significant implications of globalisation. Comprehending this at the three levels of craft, la crème, high-end and early career craft, was also considered a future requirement. A basic premise of marketing is that consumers need to want the product and therefore crafts need to raise consumer awareness, understanding and appreciation. Aligned to consumer development was the requirement for audience identification, development and nurturing. It was also noted that there is no 'champion' taking craft forward and, that the economy will continue to be lost if this is not actioned in any future plans. The focus group recommended that advice needs to be given to suppliers and that an accreditation system validating the best and minimum standard of practice may be an effective means of achieving this. The focus group method contributed to the generation of insight into how the weak economy of craft could be recovered and what measures could enhance the development of growth, specifically in Scotland. Arguably the main findings of the focus group method were the questions it raised, in relation to addressing the future of Scottish craft: Why is the market not working? What is inhibiting the sector? What are the market failures? How do we limit those failures? How can we make the supply and demand relationship work better? Where do consumers go to buy craft? Who is advising them? How do/should we market Craft the Brand? One of the key observations made was that the level of innovation in the craft sector must be developed and extended in order to provide stronger economic impact. Innovation is 
a driver of change. It was posited that if the craft economy is to survive and thrive, innovation is required in the whole range of ways that make the economy of craft; for example, how it is conceived and made by practitioners, how it is promoted by key stakeholders, bought by suppliers, managed by business and government policy, and how it is understood by consumers. The group proposed the latter observation concerning innovation be viewed as a priority. Indeed, the innovation agenda appeared to be the issue most under represented in the existing reports on craft, its market and economies.

A further observation concerned a bifurcation between practitioners who were engaged in Higher Education (H.E.) operating within the remit of the research agenda and those practitioners who operated as sole practitioners. H.E. craft researcher practitioners were looking proactively at the issues affecting craft e.g. the integration of interactive technologies and greater implementation of the method of co-design to nurture cross-disciplinary collaboration and extend the use of craft knowledge. Sole practitioners often, but not always, offered work that tended to be iterative and static in its development due to their daily focus on craft production. On further investigation, it appeared that sole practitioners work was stuck to a large degree in an economic cycle that afforded them very little time to develop their practice. Therefore their development was more incremental, as markets carried a certain expectation concerning the nature of work produced, with purchasers requiring the indexical mark of the maker to be pre-eminent. The implication of this economic model is that if they started to produce work that did not fit public and gallery management perceptions, then their market failed, resulting in an economic downturn for them and their business. A future model might then also concentrate on the transfer of marketing and other business knowledge from appropriate bodies who understand the needs of the sector; for 
example, research experts and successful practitioners could be used as sources of advice.

This approach seems preferable to approaching government support agencies which can only ever offer generic advice rather than specifically tailored assistance.

\section{Research Design Part 2:}

From the literature review and contextual analysis, it was apparent that one aspect causing difficulties for practitioners was the ability to 'get off the treadmill' and regenerate their practice through a period of research and development. Case study analysis was undertaken to investigate what progress if any, can be made when craft practitioners are offered and engage in an intensive period of research and development to raise the level of innovation in their work. The case study method adopted here is particularly useful in new and underdeveloped areas such as this (Eisenhardt 1989; Yin 2009). It is deemed appropriate when there is little known about a phenomenon, where current perspectives bring little new understanding and where existing theory is deemed inadequate or not relevant. It is believed that such circumstances apply here. The aim of case study research is to observe

the characteristics of an individual unity...to probe deeply and to analyse intensely the multifarious phenomena that constitute the life cycle of a unit with a view to establishing generalizations about the wider population to which that unit belongs (Cohen and Manion 1989: 106).

The individual unit in this situation was crafts where there was no attempt made to integrate the participants into a sample of craftspeople. By analysing participant process and outcomes, the research sought to identify similarities and differences by looking for evidence of crosscase patterns. Case study analysis permits several levels of analysis to be carried out using a variety of data collection approaches. In this study data was collected through photography, prototyping, craft products, conversation, interviews and exhibitions because of the highly visually nature of the subject under investigation. 
Over a period of three years, a total of eight participants took part in the study. Participants were selected through a national call and an externally vetted application and selection procedure. The selection criteria required submission of an up-to-date curriculum vitae, visual evidence of achievements to date via a maximum of ten image of the work, demonstration of the quality of plans for the placements via a written proposal with specific reference to how it is distinctive from existing practice, detailed budget breakdown of expenditure, detailed project management schedule and agreement to provide a full, written report on completion of the placement. Participant selection was made by an external panel of national advisors consisting of a curator, two craft practitioners, a craft educator/researcher and senior public sector manager with a craft remit. An external panel of experts was employed to ensure objectivity and reduce the level of bias toward any one individual geographic location and craft specialism.

The research and development model was viewed as an innovation in seeking to provide access to equipment, facilities and University art and design research staff as mentors as a way of creating distinctiveness in the portfolio of craft practice. It aimed to provide new pathways for approaching national and international vendors for exhibiting and retailing their work and to encourage risk taking and experimentation through its mentoring programme. Each awardee was paired with a senior researcher practitioner to ensure an enriching experience where genuine creative development was achieved. Formal mentoring is not an integral part of Scottish craft practice and was identified as a means of addressing the need for change and raising levels of innovation. Mentoring was offered as a qualitative means of supporting professional craft development and as a necessary dialogue when engaging in 
high-risk taking and experimentation strategies, an integral part of the process of innovation process (Schrage, 2000). A series of high technology workshops and seminars were offered, as was participation in creative practice research forums. A senior research active staff member was carefully selected to work with each participant, acting as a mentor. The role of mentor was to share experience and advice on topics such as creative development, enhancing professional visibility, networking with other creative and academic practitioners and overcoming barriers to career success.

The case study analysis centred on the following issues: how innovation in craft practices can be developed and extended in order to provide stronger economic impact; can an increase in the amount of research and development time within the process of making craft offer an effective means of increasing the level of innovation?; to what degree is mentoring a factor in developing creativity and innovation in craft practice?; will genuinely new ideas result from an intensive period of research and development within the sole practitioner's process of craft?; can tangible progress be made in a sole practitioner's craft through an intensive period of research and development? Questions also revolved around artist versus market orientations where some practitioners focus on producing what they want, while others respond to market forces. In order to help synthesise the findings, analysis was carried out under the themes of impact of the bursary on practice, enhancement of creativity and attitudes towards marketing.

\section{Findings Part 2:}


The results discussed here focus on three craft practitioners who have taken part in the research and development programme and who represent the range of experiences of the cohort.

Case 1 Jeannette:

Jeanette is a freelance textile artist who works with knit and felt and has also specialised in performance costume and millinery. Much of her work is centred around investigation of the body and our perceptions of it. The majority of her work is based on the body, garments and clothing and the meanings attached to it, and how it represents us (Figure 1). Her work often has a visceral quality, incorporating storytelling using a wide variety of textiles techniques. Her mentoring programme proposal described her interest in working with paper patterns for clothes making in reaction to mass production. She is interested in reacting against industrialisation of the pattern making process, and views pattern making as an intuitive process.

\section{Take in Figure 1}

\section{Impact of bursary on practice:}

Jeanette began by talking about the impact of the bursary on creative practice and experimentation in her work in textiles, leading to impact on the new product development process :

...I immediately wondered what facilities the college should have in terms of developing new...technology which I don't have access to normally, and because I've been out of college for over 10 years... But...I don't pick up on technology very easily, you know, I live very much in the past and in nostalgic worlds and so. And I think it's starting to happen now for me. 
She then considered the benefits of the bursary programme, focusing on having the time to experiment with design and materials which then impacted on the new product development process:

...most work I do is 3 dimensional so it's kind of constructed...through stitch or even gluing... So coming back to college feels it's...giving me that opportunity again...to see the possibilities of working flat and then $2 D$, and then trying to get in to $3 D$, I think college is a good place for that whereas when I'm in my [studio] I instantly roll everything into a product, 3D, because that's my income you know. So...it's not going back but it's revisiting certain practice which I did do when I was in college but I have kind of left aside a bit during my professional years and it now gives me a chance to revisit.

\section{Enhancement of creativity:}

The research and development programme has also provided her with an opportunity to explore her creativity rather than having to continually respond to customer demand (Fillis 2010). This impacts on new product development, the level of innovation in the work, marketing practice and informing overall business strategy:

...it's just different approaches...someone's giving you a different insight into your project ...it makes you experiment not more necessarily, but just from a different angle. That is the input you get... which is so important and... when you're on your own you don't get... because you do tend to [do]as normal. You go round in your own circles, you work repetitively or you go the safe way, you know, where you feel comfortable...

\section{Attitude towards marketing:}

She evaluates the importance of having a market orientation and demonstrates that operating at a lifestyle level (Ateljevic and Doorne 2000) can be more crucial and self motivating than increasing profit levels. Her comments also help to elaborate her attitudes towards branding and identity (Fillis 2003), which sometimes appear negative:

But I don't want too many [customers...So if I have 6 or 7 people come in through the door every day it's enough, you know. So I rather want to stay a small business covering the costs obviously. That's why I'm not doing retail as such, I'm not buying and selling, or I'm not 
even taking on other people's work. I wouldn't really want to be a label...My own stuff and build up a circle of customers who like it and rely on it... so when people do come either you make an appointment, I know they're coming...I don't feel I need to sell something every day. I rather...2 people come in one day a week and buy something than 20 people coming looking and pestering me, or this or that or the other. It can be very unpleasant sometimes, it's true...

Her need of marketing appears quite tightly defined and she responds to opportunities when necessary. She appears negative about formal marketing but does show evidence of entrepreneurial thinking (Fillis 2004):

I wouldn't say embrace it but I guess I stay realistic about it... But I just tend to get on with it and keep it on an essential level. I do what has to be done. I don't necessarily go out and call up magazines and say would you like to write an article about me so I don't do that but I do welcome the possibility of an opportunity comes along, I grab it, you know. I wouldn't initiate it in the first place necessarily but I think I've found an okay balance.

Case 2 Lisa:

Lisa has a first class honours degree in Textile Design and an MA in Fine Art. Textile design and craft processes have always interested her and she works at the boundaries between art and fashion (Figure 2). This is site specific in that it is informed by particular social, political and cultural climates and is often concerned with identity, conformity and difference. Her particular interest is in clothing and brand identification (Round and Roper 2012). She proposed to use the time made possible by the bursary to explore garment distortion, reconstruction and customisation in a variety of media. The bursary offered her the use of otherwise unavailable techniques, such as digital printing which would impact on her conceptual development (Figure 2).

\section{Take in Figure 2}

Impact of bursary on practice: 
It has provided her with time to reflect on how her work has evolved over time. This has also enabled her to improve time management and to consider her future direction, resulting in heightened personal confidence, innovation and new product development:

...there's basically recurrent themes that come up all the time...in my work and it's not necessarily something I'm always conscious about...it's not like I'll say I'm gonna make a piece of work about power and belonging ...it's... a theme that's... an undercurrent but it takes quite a different form...it's like a common denominator that I can track all the way back when I look at the work...Y You know if you make something you only really get a sense of what it's about...years after.

\section{Enhancement of creativity:}

Her work has been influenced by mass media imagery as well as her own creativity. She views the body as not just as a place to wear clothing but also as an exhibition space with wide reaching outcomes. She is aware of the extended boundaries of her craft beyond its traditional limits into political, social and business discourses. Her work also communicates with new audiences:

...what I'm experimenting with is how these images can be translated into cloth but then also what happens when you wear these images as well. Because...when I'm designing the pieces that are gonna be these garments I'm not necessarily thinking about how they're gonna fit the body...they're gonna become quite odd shapes and there'll be a tension that sort of sets up the tension with the body... when they're worn...The work is about our relationship with images... what I'm doing is I'm setting up...fashion images and...photo journalism, and newspaper images as an equivalent...I mean all images in a way are some form of propaganda...but also...how...that affects us, like how that shapes our perceptions of the world or perceptions of ourselves...

Propaganda is a persuasive, often political form of marketing communication (Butler and Harris 2009) and this indicates her sophisticated awareness of how creativity influences the marketing potential of her work. The creative process involves subjective, aesthetic intuitive sensing:

...You just know...like it's a feeling...I know that it's right when I see it, and I think...these pieces, the reason that I'm making quite a few of them is because they're all gonna have 
really different relationships with the body and that's... what I'm interested in...how they're gonna work.

\section{Attitudes towards marketing:}

Lisa actively embraces marketing and the commercial world in order to generate critically creative outputs from her designs as propaganda:

...I've made a collection over the past 2 months of images that for some reason I don't necessarily know why I'm attracted to. And mostly the starting point is the newspaper image, and thinking about the content or that image, and then starting to make relationships with... fashion imagery to...heighten the commodity value...of these images, so it's always about making relationships between things but that each one is quite different...

She demonstrates awareness of both the commercial and artistic value of her work. The heightening of commodity value, for example, signals an understanding of the connection with consumers (Kim 2002). The creativity demonstrated results in an innovative approach to craft as a result of its juxtapositioning with marketing and propaganda (Figure 3). Even though she engages with the commercial world and makes use of marketing, she is also keen to protect the artistic value of her work. This highlights the tension and outcomes of craft's relationships with artistic and market orientations (Fillis 2010).

Because it's not about money...That's not why I do it, at all. I do the work cos I need to do it...I wouldn't not sell the garments...but I remember I did a show in Holland and it was in a space that was a kind of art gallery but there was also high end sort of design there as well, like garments - fashion, and they did ask if I wanted to sell the garments but the price that I'd be able to sell them as clothes was a lot less than they were actually worth in terms of the labour that had gone into them, and the development that had gone into them...they're garments but they're art works which is kind of interesting I think. Like how do you sell them, how much should they sell for? They're also...one offs...but they're limited editions and all handmade.

\section{Take in Figure 3}


These comments suggest that Lisa is highly motivated and has a sense of purpose. She is also able to clearly distinguish between the pecuniary and nonpecuniary outcomes of her work (Cowen and Tabarrok 2000).

\section{Case 3 Roy:}

Roy is a designer, maker and musician who studied product design engineering. He finds new lives for old materials, seeing himself as part of a group of craft practitioners who make oneoff or small batches of products which are sometimes useful, ornamental or works of art. Previous work includes 'Ten Green Wee Shelves' made from reclaimed materials and 'Tapehead Inspector', an instrument made from a hacked cassette Walkman, video cassette, audio tape, and electronic components. He is interested in open sourcing as a means for collaboration and sustainable design. Roy is innovative and has a wide range of product ideas and a high level of technical knowledge. The bursary has given him a degree of freedom to express and develop his ideas. His craft relates more to the new product development process in the product design industry than the conventional notion of craft (Figure 4).

\section{Take in Figure 4}

His focus on open sourcing meant it would be possible to follow the development and production of the product online so that it could be reproduced and customised by the end user. Open sourcing refers to the free redistribution and access to a product's design and implementation. This philosophy connects with the notion of the consumer as co-producer where the level of involvement of the consumer is raised as they experience the coproduction (Lusch and Vargo 2006). During the duration of the bursary, Roy developed the 'Niftymitter' prototype (Figure 5): 


\section{Take in Figure 5}

This is a short-range FM transmitter based on open source hardware design. The transmitter can be used for small-scale radio broadcasts, building a distributed public address system for performances, linking a personal audio player to the car radio, or for general audio experimentation. Part of the process of developing 'Niftymitter' was documenting its progression online, and passing it on to testers who returned it with information on how they used it and how they would make improvements.

\section{Impact of bursary on practice:}

One of the benefits of the bursary is being part of a social working environment, with regular contact with other creative people with different approaches to design. This heightens the level of innovation in new product development management and impacts on the range and quality of products being produced:

I was continually asked to think in new ways, and often challenged with design values quite different to my own, which is a great source of inspiration. In this way I feel the experience has greatly improved my confidence, and opened me up to new areas of research.

The experience allowed him to create a new body of work. He is concerned with prototyping and consumer involvement in the co-production of his products:

...when I started in September...I had this other idea...the plastic one...I thought it was finished at that stage but then...I was wondering if I could reproduce it...I wanted something that would be functional at the end... But at that point I decided to redesign it quite differently really from the plastic thing...put more emphasis on the aesthetic...values of the object...So...it's a mixture of an old idea and some new inputs.

Roy's philosophy demonstrates his belief in the value of juxtapositioning, with the collaboration of the old and the new. Conventional market orientation is not followed, but consumers help shape product design and content. 
Attitude towards marketing:

Roy has a different attitude towards marketing and is keen to embrace the role of the end user in the design of the product:

...it's about empowering users, or consumers. It's the idea that if you have an object or a system that you should also have the power to change it and adapt it... That is not normally the case...in a mass produced commercial item... There's so much value put on the brand and the intellectual [aspect] that it's seen as a threat... On one level it seems a threat to allow people to hack their objects but then at the same time companies are often...sourcing ideas from their consumers...

This illustrates Roy's practical, interactive approach to marketing and new product development. Participation in the bursary programme has enabled him to think more clearly about the role of customers and his relationship with them:

...I'm thinking about sales specifically...that's one of the things...that...kind of hit me coming here was a ...need to think about the [market] more than I had been ...I'm...thinking of quite a wide audience really. It's not any specific audience cos everyone has the ability to adapt the object to them so...it makes it very hard to focus but...I'm thinking about customers...or users...

The bursary forced him to acknowledge the market and then to work with it in quite a novel way. He feels that he should only engage in the creation of products for which there is an existing need:

I would like to be responding to people's actual demands...In order to make a small business work you need to market like any other business...you invest time in developing something and then you generate interest in it...It will have come from your research which will have found that there is an interest in something, so that's always key...But...I'd only want to make things that I needed in the world. I don't want to be producing folly items that I then have to...impose on people.

Rather than controlling and owning the entire process of new product development, Roy promotes a more social role for marketing (Saren 2008) where individuals can contribute to the design process at different stages of development: 
...I think there's a difference between marketing a product and marketing oneself and that's a bit blurry when you're thinking about crafts people cos it's really hard to separate the two.... I find that quite stressful and it means making all sorts of compromises, whereas I feel like I can market myself as a person all right...I'd love to...just have a regular job as someone who makes stuff, and someone else who's good at marketing the sales can deal with ...the way the product interfaces with buyers....so I can...actually just leave it, I can just do as much as I want... and then someone else can pick it up and do the next stage in the development... and it appeals to me to not have to necessarily deal with that, with every stage of the development. And likewise, I can pick someone else's and do a bit of development on it.

Analysis of the data has shown that the introduction of the research and development programme has resulted in a number of benefits. There is evidence that the makers have been able to experiment with their designs in developing new products and also in terms of evaluating different approaches to marketing. Instead of spending most of their day making craft products with little creative advancement, they have been able to reflect on their approaches and move forward in innovative ways. For two of the practitioners, marketing is now embedded in craft practice while the other maker acknowledges its importance but this is balanced against lifestyle and aesthetic philosophies. As is found in small businesses in other sectors, the owner/manager has adapted elements of marketing which best suit the situation specific requirements of the business. The mentoring programme, while improving craft skills, has also resulted in improved networking with other makers and also raised competency levels through interaction with skilled, experienced academic practitioners.

\section{Discussion and implications for theory and practice:}

Contemporary craft practice is not solely associated with the interpretation by Fillis (2002; 2004) which focuses on hand-made individual or small batch outputs which may or may not be culturally embedded in the country of production and sold for profit. By combining 
perspectives from small business marketing and craft's artistic, political, economic, cultural and consumerist influences, an alternative understanding can be obtained which can be used to provide leverage for securing the future economy of craft (Dormer 1997; Kim 2002; Fillis 2004; 2006; Valentine 2010; Von Busch 2010). This can be researched by viewing craft as an intellectual activity with dynamic and transformative meaning, purpose, aesthetic and economy (Valentine and Follett 2010). The benefits of the research and development programme have been realised in the refreshing of craft practice by the individuals analysed in the case studies. The intervention of mentoring (Scandura et al. 1996; Megginson 2000) and access to marketing advice appears to have impacted positively on practice.

During the interviews with the bursary recipients, it became clear that the programme of research and development was beginning to have an impact both in terms of craft practice and with respect to practitioner philosophy and critical reflection over time. Even with this time for reflection, some outcomes may not be immediately obvious in the short term but may emerge over a longer period. Since pursuing a career in craft can often be a lonely experience, participation in the programme enabled the individuals to interact with other creative people so that ideas could be exchanged as well as the development of additional creative competencies leading to innovative practices (Agor 1986; Bjorkman 2002; Fillis 2006; Fillis and Rentschler 2005).

Rather than expressing their use of marketing in formal terms, the participants adopted informal, intuitive attitudes towards it which is more akin to small business practitioners elsewhere (Gilmore et al. 2001; O’Donnell 2004). Marketing was being used not only to help secure a level of income but also to contribute towards lifestyle and to address other social 
concerns (Andreasen 1994; Ateljevic and Doorne 2000). Both reactive and proactive approaches to marketing were in evidence (Carson 1990; Carson 1993; O’Dwyer et al. 2009). Even though the value of marketing was acknowledged by all the participants, they also emphasised the need for artistic integrity alongside customer interaction.

A key issue then is whether this research and development programme can be deemed a successful intervention. Future work needs to be carried out on how such policies can inform practice, not just in craft, but in the wider small and medium sized environment where creativity, innovation and experimentation can be used to generate new solutions which excite the marketplace. The bursary programme continues to be implemented and it is the intention to carry out longitudinal research into the impact of the programme on craft practice over time. Future bursary programmes with a range of time frames and structures must bring marketing into the dialogue much earlier. Considering marketing only at the end or near the end of the new product development process is hindering the craft sector.

There is evidence that research and development programmes of this nature benefit practitioners, helped by the mentoring process. However, longitudinal analysis of the development of the business and the owner/manager practitioner over time is required to ensure that the benefits are not only maintained but are accentuated. Programmes of this nature enable suitable time for reflection of craft practice but also for analysis of marketing requirements. This would not necessarily be the case in the day to day operation of the business. So future research should analyse the cases assessed over time in order to identify competency development and future needs requirements with respect to craft and marketing skills. 


\section{References}

Adamson, G. (Ed.) (2010), The Craft Reader, Berg, London.

Agor, W. (1986), The Logic of Intuitive Decision Making: a Research-Based Approach for Top Management", Quorum, New York.

Andreasen, A.R. (1994), "Social marketing: its definition and domain", Journal of Public Policy and Marketing, Vol.13 No.1, pp. 108-114.

Ateljevic, I. and Doorne, (2000), "Staying within the fence: lifestyle entrepreneurship in tourism”. Journal of Sustainable Tourism. Vol.8 No.5, pp. 378-392.

Bjorkman, I. (2002), "Aura: aesthetic business creativity", Consumption, Markets and Culture Vol.5 No.1, pp.69-78.

Blackler, F.H.M. and Brown, C.A. (1983), "Qualitative research and paradigms of practice," Journal of Management Studies, Vol.20 No.3, 349-366.

BOP Consulting (2012), Craft in an Age of Change: Summary Report, prepared for Creative Scotland, Crafts Council, Arts Council of Wales and Craft Northern Ireland.

Bryman, A and Burgess, R.G. (1995), "Developments in qualitative data analysis: an introduction", in Bryman, A. and Burgess, R.G. (Eds.) Analysing Qualitative Data, Routledge, London.

Butler, P. and Harris, P. (2009), "Considerations on the evolution of political marketing theory”, Marketing Theory, Vol.9 No.2, pp.149-164.

Carson, D.J. (1993), "The evolution of marketing in small firms", European Journal of Marketing, Vol. 19 No.5, pp.7 - 16.

Carson, D. (1990), "Some exploratory models for assessing small firms' marketing performance (a qualitative approach)", European Journal of Marketing, Vol.24, No1, pp.851.

Cohen L and L Manion (1989), Research Methods in Education, Routledge, London.

Cowen, T. and Tabarrok, A. (2000), "An economic theory of avant-garde and popular art, or high and low culture", Southern Economic Journal, Vol. 67 No 2, pp. 232-253.

Day, G.S. and Wensley, R. (1988), "Assessing advantage: a framework for diagnosing competitive superiority", Journal of Marketing, Vol. 52 No. 2, pp. 1-20.

Davies, R. and Lindley, R. (2003), Artists in Figures: A Statistical Portrait of Cultural Occupations. Arts Council of England, London. 
Dean, D. (1994), "A slipware dish by Samuel Malkin: an analysis of vernacular design", Journal of Design History, Vol.7 No.23, p153.

Doane, M.A. (2003), The Emergence of Cinematic Time: Modernity, Contingency, the Archive, Cambridge MA: Harvard University Press, p. 25.

Dormer, P. (1997), “The salon de refuse?” in Dormer, P. (Ed.), The Culture of Craft - Status and Future, Manchester University Press, Manchester.

Enright, M. (1999), "Can there be different forms of market orientation and new product development?", Industrial Management and Data Systems, Vol. 99, No. 3, pp. 118-133.

Eisenhardt, K.M. (1989), "Building theories from case study research", Academy of Management Review, Vol.14 No.4, pp.532-550.

Fillis, I. (2002), "Barriers to internationalisation: an investigation of the craft microenterprise", European Journal of Marketing, Vol.36 Nos. 7/8, pp.912-927.

Fillis, I. (2003), "Image, reputation and identity Issues in the arts and crafts organisation", Corporate Reputation Review: An International Journal, Vol.6 No.3, pp.239-251.

Fillis, I. (2004), "The internationalising smaller craft firm: insights from the marketing and entrepreneurship interface”, International Small Business Journal, Vol.22 No.1, pp.57-82.

Fillis, I. (2006), “Art for art's sake or art for business sake: an exploration of artistic product orientation", The Marketing Review, Vol.6, No.1, pp.29-40.

Fillis, I. (2010), "The tension between artistic and market orientation in visual art", in O'Reilly, D. and Kerrigan, F. (Eds.) Marketing the Arts: A Fresh Approach, Routledge, London, pp.31-39.

Fillis, I. and Rentschler, R. (2005), Creative Marketing: an Extended Metaphor for Marketing in a New Age, Palgrave Macmillan, Basingstoke.

Follett, G. and Valentine, L. (Eds.) (2007). New Craft - Future Voices Conference Proceedings, Duncan of Jordanstone College of Art and Design, University of Dundee, July $4^{\text {th }}-6$ th.

Galloway, S., Lindley, R., Davies, R. and Scheibl, F. (2002), A Balancing Act: Artists' Labour Markets and the Tax and Benefit Systems, Arts Council of England, London.

Gilchrist, V.J. (1992), "Key informant interviews", in Crabtree, B.F. and Miller, W.L. (eds.), Doing Qualitative Research, Sage, London.

Gilmore, A., Carson, D. and Grant, K. (2001), "SME marketing in practice", Marketing Intelligence and Planning, Vol.19 No.1, pp.6-11. 
Greenhalgh, P. (2010), "Craft and the new humanism", in Valentine, L. and Follett, G. (Eds.) (2010). Past, Present and Future Craft Practice, Duncan of Jordanstone College, National Museums of Scotland and the University of Dundee, pp.98-105.

Hartley, J. (2005), Creative Industries, WileyBlackwell, Oxford.

Hesmondhalgh, D. (2007), The Cultural Industries, Sage, London.

Heslop, T.A. (1997), "How strange the change from major to minor: hierarchies and medieval art", in Dormer, P. (Ed.), The Culture of Craft, Manchester University Press, Manchester, pp.53-66.

HiArts, Glasgow Grows Audiences and the Audience Business (2009), Futurefocus: Developing audiences for Scottish craft, report for the Scottish Arts Council, Edinburgh.

Hillman-Chartrand, H. (1988), "The crafts in the post-modern economy," Journal of Cultural Economics, Vol. 12 No.2, pp39-66.

Higgs, P. and Cunningham, S. (2008), 'Creative industries mapping: where have we come from and where are we going?', Creative Industries Journal, Vol.1 No.1, pp.7-30.

Kim, J-K. (2002), "Consumer value: an application to mall and Internet shopping", International Journal of Retail \& Distribution Management, Vol. 30 No.12, pp.595 - 602.

Knott, C.A. (1994), Crafts in the 1990s. A Socio-economic study of craftspeople in England, Scotland and Wales, Crafts Council, London.

Kristellar, P.O. (1951), "The modern system of the arts: a study in the history of aesthetics part 1", Journal of the History of Ideas, Vol.12 No.4, p496-527

Lusch, R. F. and Vargo, S. L. (2006), "Service dominant logic- reactions, reflections and refinements", Marketing Theory. Vol. 6 No.3, pp281-288.

McAuley, A. and Fillis, I. (2002), Crafts businesses in Scotland: a Study, report for The Scottish Arts Council, Scottish Enterprise and Scottish Enterprise Glasgow, Glasgow.

McAuley, A. and Fillis, I. (2004), Making It In the Twenty-First Century: A Socio-Economic Study of Craftspeople in England and Wales 2003/2004. Report for Crafts Council and Arts Councils of England and Wales, London.

McAuley, A. and Fillis, I. (2006), A Future in the Making: A Socio-Economic Study of Makers in Northern Ireland. Report for Craft Northern Ireland, Belfast.

McAndrew, C. (2002), Artists, Taxes and Benefits. London: Arts Council of England.

Marshall, J. (2007), "Coded ornament: contemporary plasterwork and the use of digital technologies", The Design Journal, Vol. 10 No.2, p.p4-21 
Megginson, D. (2000), "Current issues in mentoring", Career Development International, Vol.5 No.4/5, pp.256-260.

Metcalf, B. (1997), 'Craft and art, culture and biology', in Dormer, P. (Ed.), The Culture of Craft - Status and Future, Manchester University Press, Manchester.

Miller, D. (2009), Stuff, Polity Press, Cambridge.

Millman, M. (2006), Origin 2006 Research, report for the Crafts Council, London.

Morgan, D.L. (1988), Focus Groups as Qualitative Research, Newbury Park, CA., Sage.

Morris Hargreaves McIntyre (2006), Making it to Market: Developing the Market for Contemporary Craft, Arts Council, London.

Niedderer, K. and Townsend, K. (2010), “Editorial”, Craft Research, Vol.1 No.1, pp.3-10.

O'Donnell, A. (2004), "The nature of networking in small firms", Qualitative Market Research: An International Journal, Vol.7 No.3, pp.206-217.

O'Dwyer, M., Gilmore, A. and Carson, D., (2009), "Innovative marketing in SMEs", European Journal of Marketing, Vol. 43 Nos.1/2, pp.46 - 61.

Platinum Consulting Group (2006), Sectoral Analysis of the Irish Craft Industry, report for the Crafts Council of Ireland, Kilkenny.

Pratt, A.C. (2004), "The cultural economy: a call for spatialised "production of culture" perspectives', International Journal of Cultural Studies, Vol.7 No.1, pp.117-128.

Risatti, H. (2007), A Theory of Craft, University of North Carolina Press, Chapel Hill.

Roodhouse, S. (2006), 'The creative industries: definitions, quantification and practice', Conference Proceedings of Cultural Industries: The British Experience in International Perspective, Centre for British Studies, Huboldt-Universitat, Berlin.

Round, D.J.G. and Roper, S. (2012), "Exploring consumer brand name equity: Gaining insight through the investigation of response to name change", European Journal of Marketing, Vol. 46 Nos7/8, pp.938 - 951.

Saren, M. (2008), "Social marketing", European Journal of Marketing, Vol. 42 Nos. 9/10, pp. $1133-1134$.

Scandura, T.A., Tejeda, M.J., Werther, W.B and Lankau, M.J. (1996), "Perspectives on mentoring”, Leadership and Organization Development Journal, Vol.17 No.3, pp.50-56.

Schrage, M. (2000), Serious Play: How the World's Best Companies Simulate to Innovate, Harvard Business School Press, Boston, MA. 
Scotinform Ltd. (2007), Crafts Audiences in Scotland, report for Scottish Arts Council, Edinburgh.

Schroeder, J.E. (2005), "The artist and the brand", European Journal of Marketing, Vol. 39 No.11, pp. $1291-1305$.

Stevenson, F. (2007), "Achieving balance - making a living in craft", Neocraft, Conference paper, Nova Scotia College of Art and Design, Halifax, Canada, 23-25 November 2007.

Stevenson, F. and Scobie, L. (2007), "Natural forces - dynamic ingredients for creative practice", in New Craft - Future Voices, Conference Proceedings, Duncan of Jordanstone College of Art and Design, University of Dundee, July $4^{\text {th }}-6^{\text {th }}$, pp.123-133.

Storey, J. (1994), Understanding the Small Business Sector, International Thomson Business Press, London.

Valentine, L. (2010), "Past and present craft practice: a frame of reference for mindful inquiry research and future craft", in Valentine, L. and Follett, G. (Eds.) (2010). Past, Present and Future Craft Practice, Duncan of Jordanstone College, National Museums of Scotland and the University of Dundee, pp.72-83.

Valentine, L. and Follett, G. (eds.) (2010), Past, Present and Future Craft Practice, Duncan of Jordanstone College, National Museums of Scotland and the University of Dundee.

Von Busch, O. (2010), "Exploring net political craft: from collective to connective", Craft Research, Vol.1, pp.113-124.

Wilkinson, S. (2004), "Focus group research", in Silverman, D. (Ed.), Qualitative Research Theory, Method and Practice, Sage, London.

Yair, K., Press, M and Tomes, A. (2001), 'Crafting competitive advantage: crafts knowledge as a strategic resource, Design Studies, Vol.22 No.4, pp.377-394.

Yin, R.K. (2009), Case Study Research: Design and Methods, Sage, London. 
Figure 1: Right Hand Image is an example of pre-bursary craft practice and Left Hand Image is an example of the craft practice resulting from the bursary, demonstrating a shift from commercial to conceptual, small scale to large scale.

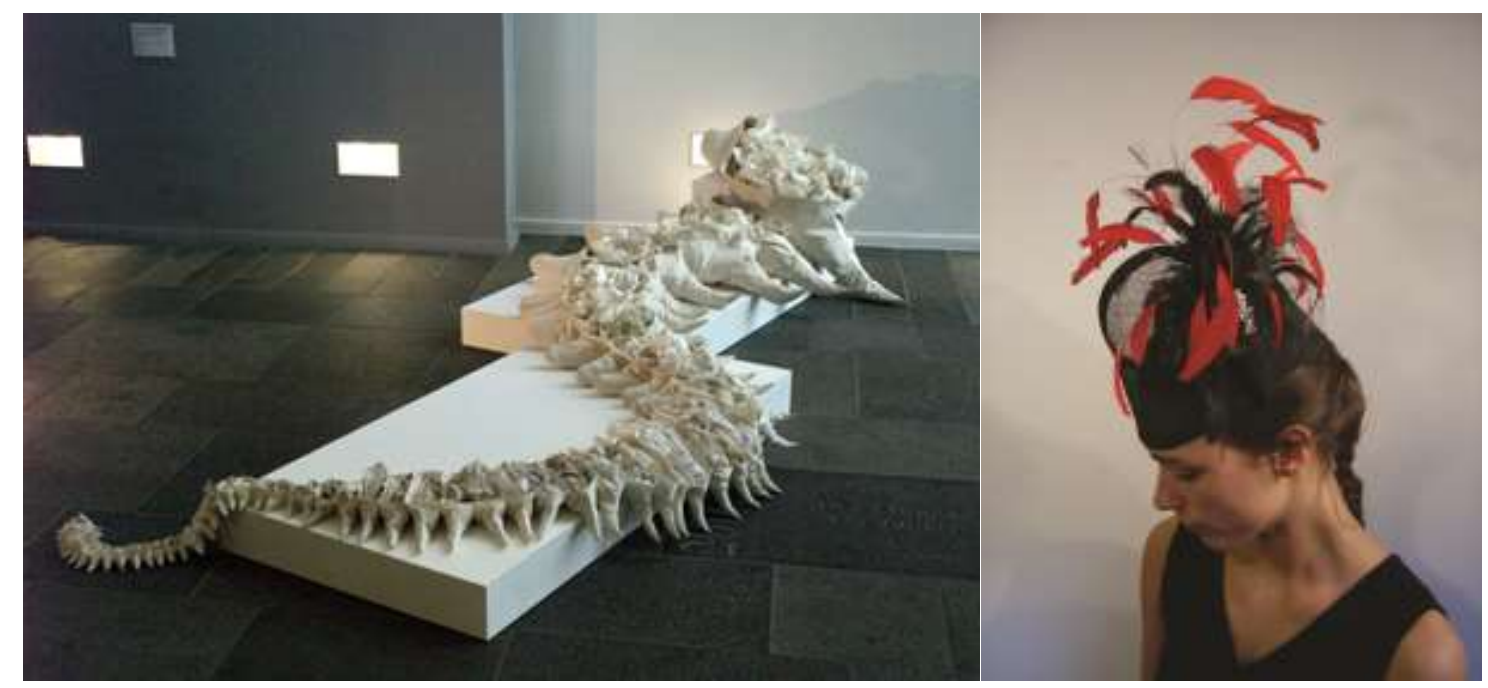


Figure 2 Example of Pre-Bursary Craft Practice:

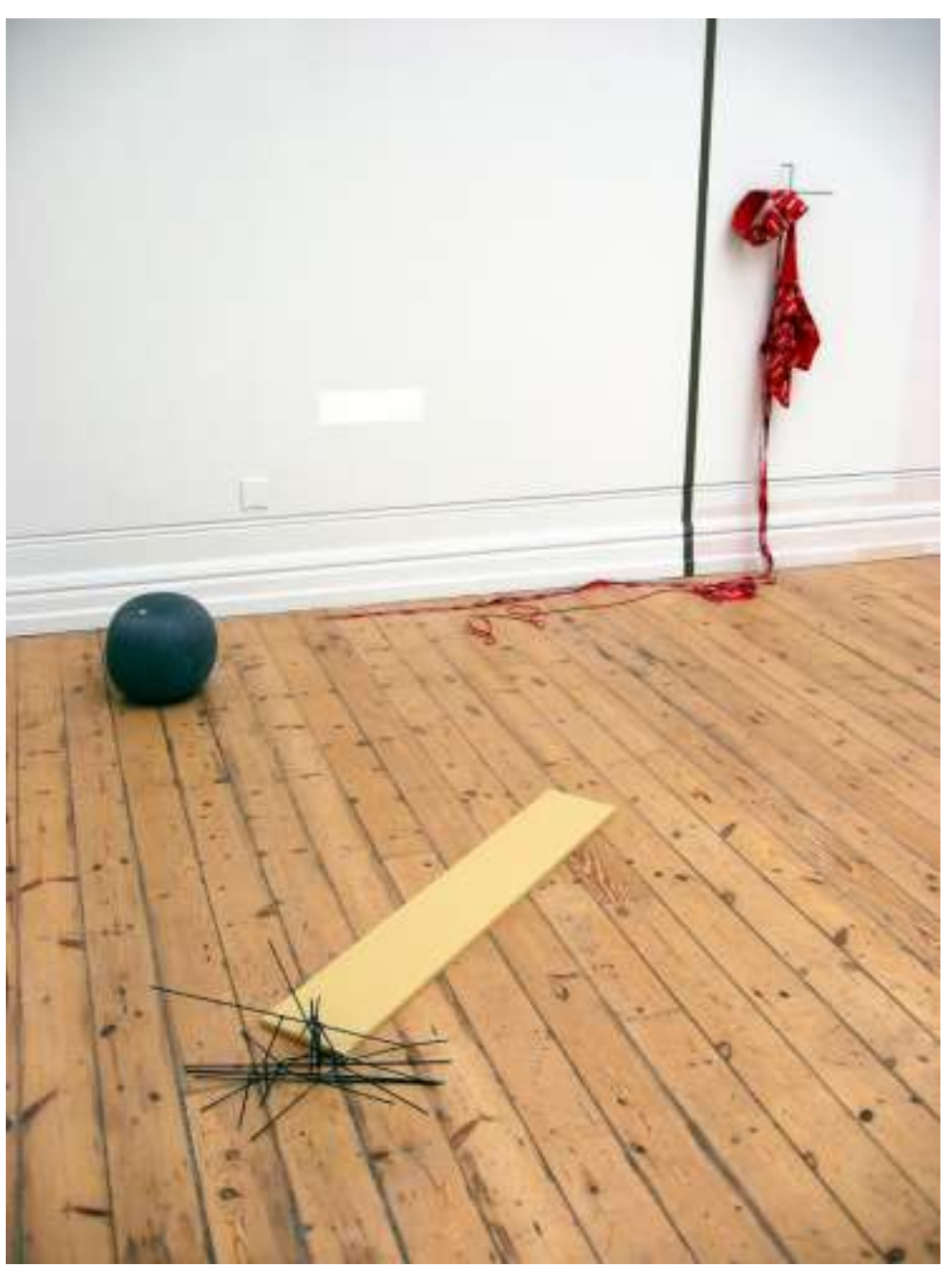


Figure 3 Example of Craft Practice at the end of the Bursary Programme:

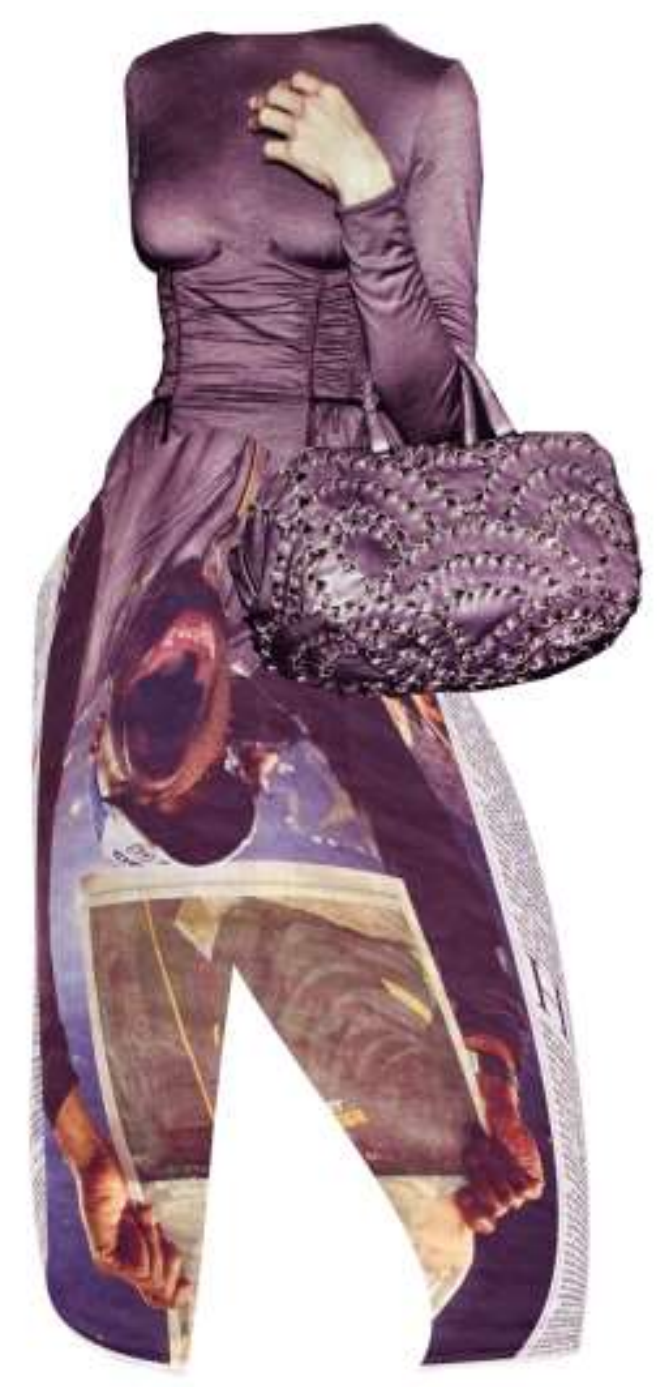


Figure 4 Example of Pre-bursary craft practice

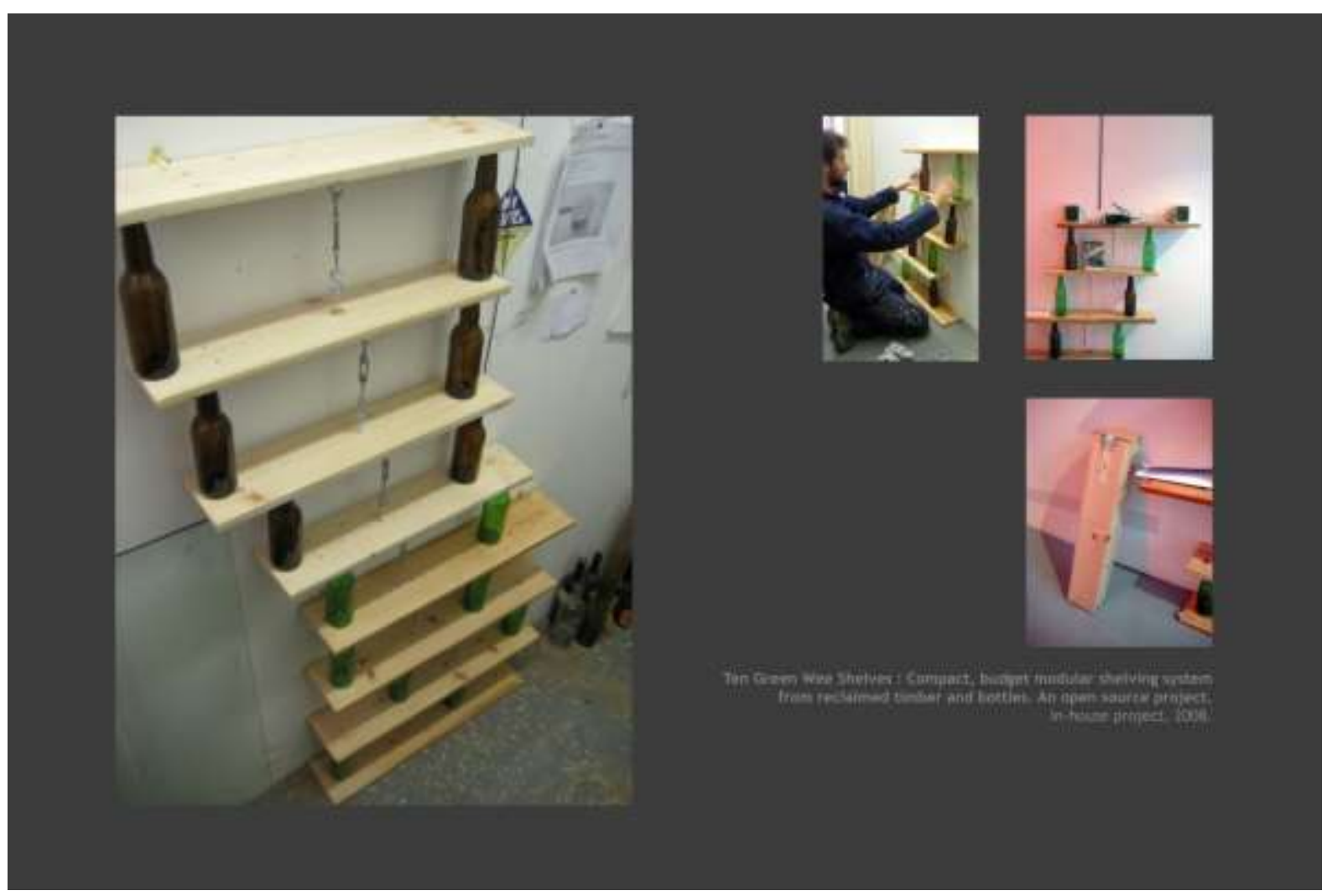


Figure 5 Example of Craft Practice at the end of the Bursary Programme:

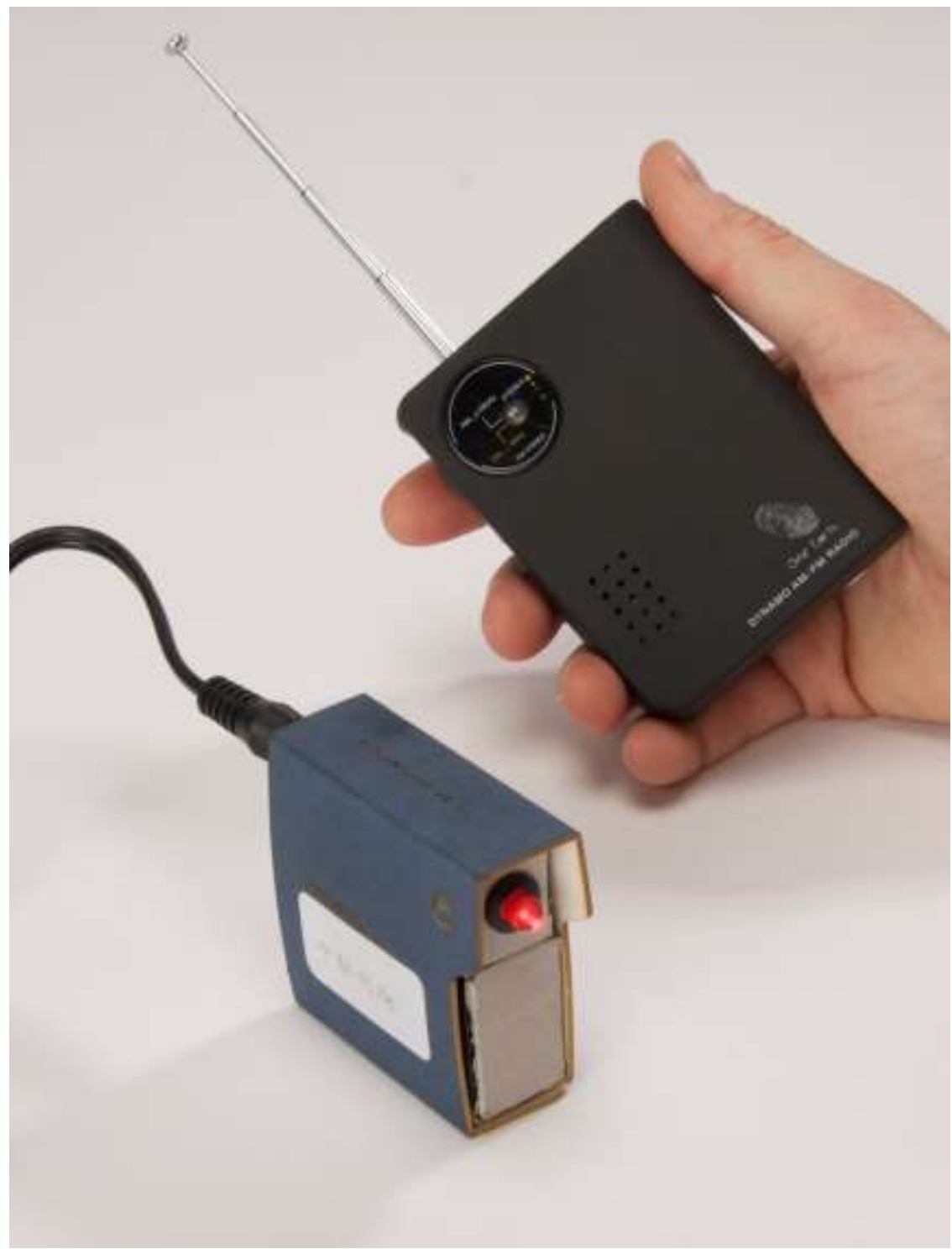

